\title{
PENGARUH KOMPENSASI DAN DISIPLIN KERJA TERHADAP PRODUKTIVITAS KERJA KARYAWAN PADA MECHANICAL DIVISION PT MULIA MAKMUR ELEKTRIKATAMA
}

\author{
Nidaul Izzah dan Ida Ardiani \\ Institut Ilmu Administrasi Mandala Indonesia \\ nida.achis@yahoo.com
}

\begin{abstract}
Abstrak. Maksud dari penelitian ini adalah untuk mendapatkan informasi mengenai pengaruh kompensasi dan disiplin kerja terhadap produktivitas kerja karyawan, sedangkan tujuan adalah untuk memperoleh data secara empiris sejauh mana pengaruh kompensasi dan disiplin kerja dalam meningkatkan produktivitas kerja karyawan, metode analisis data yang digunakan adalah metode kuantitatif. Metode kuantitatif digunakan untuk mengetahui hubungan antara variabel kompensasi (X1) dan variabel disiplin kerja (X2) terhadap produktivitas kerja karyawan (Y).

Sampel penelitian adalah karyawan pada mechanical division PT Mulia Makmur Elektrikatama Jalan Jababeka VIIIA SFB Blok B 11 V Cikarang Bekasi, pengambilan sampel dilakukan dengan cara "random sampling". Setelah meneliti hasil isian kuesioner yang telah disebarkan kepada karyawan dan perhitungan korelasi antara kompensasi dan disiplin kerja terhadap produktivitas kerja maka dengan menggunakan perhitungan regresi berganda diperoleh : $\mathrm{Y}=0,0102+0,2149 \mathrm{X} 1+0,7998 \mathrm{X} 2$ dengan $\mathrm{b} 1=0,2149$ mempunyai arti hubungan kompensasi (X1) dengan produktivitas (Y) positif dan b2 $=0,7998$ mempunyai arti hubungan disiplin kerja (X2) dengan produktivitas (Y) positif. Sedangkan hasil analisis dengan menggunkan perhitungan korelasi berganda diperoleh $\mathrm{R}=0,9113$ dan $\mathrm{KPB}=83,05 \%$ yang berarti ada hubungan positif dan sangat kuat antara kompensasi (X1) dan disiplin kerja (X2) secara bersama-sama terhadap produktivitas kerja $(\mathrm{Y})$ dan $16,95 \%$ kontribusinya berasal dari faktor-faktor di luar penelitian ini. Adapun hasil uji-F menunjukkan Fhitung > Ftabel atau 66,13\% > 3,35 yang berarti semua variabel bebas (kompensasi $=\mathrm{X} 1$, disiplin kerja $=\mathrm{X} 2$ ) secara bersama-sama terdapat pengaruh yang signifikan terhadap variabel produktivitas kerja (Y) pada mechanical division PT Mulia Makmur Elektrikatama.
\end{abstract}

Kata Kunci : kompensasi, disiplin kerja, produktivitas, PT Mulia Makmur Ektrikatama, regresi linier berganda

\begin{abstract}
The purpose of this study was to obtain information about the influence of compensation and working discipline on employee productivity, while the purpose is to obtain data empirically the extent of the influence of compensation and working discipline in increasing productivity employee. The data analysis method used is quantitative method. Quantitative methods are used to determine the relationship between the variable compensation (X1) and variable work discipline (X2) on employee productivity (Y).

Samples were employees at mechanical division of PT Mulia Makmur Jalan Jababeka VIIIA Elektrikatama SFB Block B 11 V Cikarang Bekasi, sampling is done by random sampling. After examining the completed questionnaires that have been distributed to the employees and the calculation of the correlation between compensation and discipline against the labor productivity by using multiple regression calculations obtained: $\mathrm{Y}=0.0102+0,2149 \mathrm{X} 1+0,7998 \mathrm{X} 2$ with $\mathrm{b} 1=0.2149$ have meaning relationships compensation (X1) and productivity (Y) is positive and $\mathrm{b} 2=0.7998$ has meaning relations work discipline $(\mathrm{X} 2)$ and productivity $(\mathrm{Y})$ is positive. While the analysis results obtained using the calculation of multiple correlation $\mathrm{R}=0.9113$ and $\mathrm{KPB}=83.05 \%$, which means there is a very strong positive relationship between compensation and (X1) and discipline (X2) together to work productivity (Y) and $16.95 \%$ contribution comes from factors outside of this study. The F-test results showed Fhitung > Ftabel or 66.13\%> 3.35, which means all of the independent variable (compensation $=\mathrm{X} 1, \mathrm{X} 2=$ work discipline) together there is a significant effect on work productivity variable (Y) on the mechanical PT Mulia Makmur Elektrikatama division.
\end{abstract}

Key Words: Compensation, Discipline, Productivity, PT Mulia Makmur Ektrikatama, Multiple Linear Regression 
Nidaul Izzah dan Ida Ardiani, Pengaruh Kompensasi dan Disiplin Kerja ...

Pada dasarnya setiap organisasi/ perusahaan yang didirikan mempunyai harapan bahwa kelak di kemudian hari akan mengalami perkembangan yang pesat di dalam lingkup kegiatannya dan menginginkan terciptanya produktivitas yang tinggi dalam bidang pekerjaannya. Perkembangan ini berdampak pada persaingan yang semakin ketat, terutama dalam usaha untuk memenuhi kebutuhan para pelanggan. Kompleksitas persaingan pun meningkat karena kehadiran para pendatang baru dalam pasar. Persaingan yang ketat tersebut dapat menyebabkan ancaman bagi eksistensi perusahaan, karena konsumen dihadapkan pada banyak pilihan produk/jasa yang sama yang juga ditawarkan oleh perusahaan lain. Konsumen akan menentukan pilihan terbaik, dengan memilih produk/jasa yang memiliki kualitas lebih baik, lebih murah dan lebih terpercaya. Oleh karena itu, sebagai salah satu pelaku industri selain harus peka terhadap perubahan yang terjadi, perusahan juga harus meningkatkan daya saing mereka agar bisa terus bertahan dan berkembang.

Dalam kenyataannya produktivitas kerja karyawan seringkali mengalami masalah, diantaranya seringkali target pekerjaan tidak tercapai, karyawan sering mangkir/bolos/sakit, absensi tidak tepat waktu, kekompakkan tim kurang solid, dll

Berdasarkan dari uraian-uraian di atas, penulis mempunyai keinginan yang kuat untuk mengetahui apakah ada pengaruh kompensasi dan disiplin kerja terhadap produktivitas kerja yang dituangkan dalam penelitian yang berjudul " Pengaruh Kompensasi dan Disiplin Kerja Terhadap Produktivitas Kerja Karyawan Pada Mechanical Division PT Mulia Makmur Elektrikatama".

\section{Perumusan Masalah}

Berdasarkan latar belakang yang telah dikemukakan di atas, maka dapat dirumuskan permasalahan sebagai berikut: 1. Apakah ada pengaruh kompensasi terhadap peningkatan produktivitas kerja karyawan PT. Mulia Makmur Elektrikatama?; 2. Apakah ada pengaruh disiplin kerja terhadap peningkatan produktivitas kerja karyawan PT. Mulia Makmur Elektrikatama?; dan 3. Apakah ada pengaruh kompensasi dan disiplin kerja terhadap peningkatan produktivitas kerja karyawan PT. Mulia Makmur Elektrikatama?

\section{Tujuan Penelitian}

Tujuan dari penelitian ini adalah : 1). Untuk mengetahui pengaruh kompensasi terhadap peningkatan produktivitas kerja karyawan PT. Mulia Makmur Elektrikatama; 2). Untuk mengetahui pengaruh disiplin kerja terhadap peningkatan produktivitas kerja karyawan PT. Mulia Makmur Elektrikatama; dan 3). Untuk mengetahui pengaruh kompensasi dan disiplin kerja terhadap peningkatan produktivitas kerja PT. Mulia Makmur Elektrikatama.

\section{KAJIAN TEORI}

\section{Pengertian Kompensasi}

Perusahaan mengharapkan agar kompensasi yang dibayarkan memperoleh imbalan produktivitas kerja yang lebih besar dari karyawan. Jadi, nilai produktivitas kerja karyawan harus lebih besar dari kompensasi yang dibayarkan perusahaan, supaya perusahaan mendapatkan laba dan kontinuitas perusahaan terjamin. Sedangkan cara departemen personalia meningkatkan prestasi kerja, motivasi dan kepuasan kerja karyawan adalah melalui kompensasi.

Menurut Malayu S.P Hasibuan ( 2010:118 ) Kompensasi adalah semua pendapatan yang berbentuk uang, barang langsung atau tidak langsung yang diterima karyawan sebagai imbalan atau jasa yang diberikan kepada perusahaan. Menurut Handoko ( 2007: 155) salah satu cara untuk meningkatkan prestasi adalah melalui pemberian kompensasi. Kompensasi adalah segala sesuatu yang diterima karyawan, sebagai salah satu bentuk balas jasa atas pekerjaan yang mereka

lakukan.

Menurut Henry Simamora ( 2004:442 ) kompensasi adalah apa yang diterima oleh para karyawan sebagai ganti kontribusi mereka kepada organisasi.

Dari pengertian berikut dapat disimpulkan bahwa kompensasi adalah semua bentuk pembayaran yang diberikan oleh perusahaan kepada karyawan sebagai balas jasa atas pelaksanaan tugas atau kontribusi karyawan 
kepada perusahaan. Besarnya balas jasa atau kompensasi telah ditentukan dan diketahui sebelumnya, sehingga karyawan secara pasti mengetahui besarnya balas jasa atau

kompensasi yang akan diterimanya. Kompensasi inilah yang akan dipergunakan karyawan beserta keluarganya untuk memenuhi kebutuhan-kebutuhannya. Besarnya kompensasi mencerminkan status, pengakuan, dan tingkat pemenuhan kebutuhan yang akan doterima oleh karyawan. Jika balas jasa yang diterima karyawan semakin besar berarti jabatannya semakin tinggi, statusnya semakin baik, dan pemenuhan kebutuhan yang dinikmatinya semakin banyak pula. Dengan demikian kepuasan kerjanya juga semakin baik, disinilah letak pentingnya kompensasi bagi karyawan sebagai seorang penjual tenaga (fisik dan fikiran).

\section{Jenis-jenis Kompensasi}

Menurut Henry Simamora ( 2004:461 ) kompensasi dibedakan menjadi dua yaitu :

Kompensasi Langsung ( Direct Compensation )

Kompensasi langsung merupakan penghargaan yang diterima karyawan dalam bentuk uang. Kompensasi langsung dapat berupa: 1) Gaji adalah kompensasi atau balas jasa yang dibayarkan secara periodik kepada karyawan tetap serta mempunyai jaminan yang pasti 2) Upah adalah kompensasi atau balas jasa yang dibayarkan kepada karyawan harian dengan berpedoman atas perjanjian yang telah disepakati 3) Insentif adalah kompensasi atau balas jasa yang diberikan kepada karyawan tatap yang berprestasi 4) Bonus, Jenis kompensasi lain yang ditetapkan adalah berupa pemberian bonus. pemberian bonus kepada karyawan dimaksudkan untuk meningkatkan produktivitas kerja karyawan.

\section{Kompensasi Tidak Langsung ( Indirect Compensation )}

Kompensasi tidak langsung adalah kompensasi yang tidak dirasakan secara langsung oleh karyawan, yakni benefit dan service. Kompensasi ini merupakan kompensasi tambahan yang diberikan baik finansial maupun non finansial yang diberikan berdasarkan kebijaksanaan-kebijaksanaan perusahaan terhadap semua karyawan. Kompensasi tidak langsung berupa: a) Pembayaran upah untuk waktu tidak bekerja b) Perlindungan ekonomis terhadap bahaya, meliputi : tunjangan hari tua, tunjangan pengobatan, rencana pensiun. c) Program pelayanan karyawan, meliputi: rekreasi, kafetaria, perumahan, beasiswa pendidikan, dan fasilitas lainnya.

\section{Indikator-Indikator Kompensasi}

Adapun yang menjadi bahan utama sebagai indikator untuk kompensasi menurut Randall S. Schuler ( 2000:86 ) adalah pengembangan karir, kenaikan penghasilan, jaminan asuransi, kenyamanan tugas, persahabatan, tunjangan jabatan, pembayaran tidak masuk kantor, bonus dan insentif.

\section{Sedangkan menurut Simamora}

2004:445 ) indikator-indikator kompensasi diantaranya: a) Upah dan Gaji, yaitu kompensasi atau balas jasa yang diberikan secara periodik kepada karyawan tetap serta mempunyai jaminan yang pasti. Sedangkan upah adalah kompensasi atau balas jasa yang dibayarkan kepada karyawan harian dengan berpedoman atas perjanjian yang telah disepakati, b) Insentif adalah kompensasi atau balas jasa yang diberikan kepada karyawan tetap yang berprestasi, c) Tunjangan, contoh tunjangan adalah asuransi kesehatan dan jiwa, liburan yang ditanggung perusahaan, program pensiun, dan tunjangan lainnya yang berkaitan dengan hubungan kepegawaian, d) Fasilitas, contohnya, parkir khusus karyawan, kafetaria, mobil perusahaan, dan fasilitas lainnya yang diberikan oleh perusahaan kepada para karyawannya.

\section{Hubungan Kompensasi Produktivitas Kerja Karyawan}

Terhadap Pemberian kompensasi didalam suatu perusahaan merupakan salah satu faktor pendukung di dalam usaha perusahaan untuk memotivator para karyawannya dalam meningkatkan produktivitas kerjanya. Teori yang menghubungkan antara kompensasi terhadap produktivitas kerja karyawan dikemukakan oleh Komaruddin (2004:112) bahwa: "Faktor-faktor yang mempengaruhi tinggi rendahnya produktivitas antara lain besarnya pendapatan dan jaminan sosial, kompensasi, tingkat pendidikan dan latihan, 
Nidaul Izzah dan Ida Ardiani, Pengaruh Kompensasi dan Disiplin Kerja ...

sikap, disiplin, moral dan etika kerja, motivasi, kesehatan, lingkungan dan iklim kerja, hubungan insani, kepuasan, teknologi, dan kebijaksanaan pemerintah". Teori tersebut didukung pula oleh pendapat Sedarmayanti (2010:31) yaitu "Banyak aktivitas yang dilaksanakan dalam sistem sumber daya manusia dirancang untuk mempengaruhi produktivitas individual atau organisasional. Penggajian, sistem penilaian, pelatihan, seleksi, desain pekerjaan, dan kompensasi adalah aktivitas sumber daya manusia yang berkaitan langsung dengan produktivitas".

Pendapat di atas menjelaskan bahwa kompensasi merupakan salah satu faktor yang mempengaruhi tinggi rendahnya produktivitas kerja karyawan di dalam suatu perusahaan.

\section{Pengertian Disiplin Kerja}

Disiplin merupakan fungsi operatif manajemen sumber daya manusia yang sangat penting karena semakin baik disiplin karyawan, semakin tinggi produktivitas kerja yang dapat dicapai perusahaan. Disiplin karyawan pada suatu perusahaan merupakan masalah yang perlu diperhatikan, karena masalah ini dapat mengakibatkan maju mundurnya perusahaan. Perusahaan tidak akan mengalami kemajuan dan perkembangan bila disiplin karyawan tidak diterapkan, sehingga dapat mengakibatkan kehancuran bagi perusahaan yang bersangkutan. Adapun pengertian tentang masalah disiplin yang sebenarnya maka berikut ini penulis akan mengetengahkan beberapa teori atau pendapat para ahli, antara lain sebagai berikut :

T. Hani Handoko ( 2007:115 ) mengemukakan bahwa Kedisiplinan adalah kegiatan manajemen untuk menjalankan standar-standar organisasional.

Menurut Malayu S.P Hasibuan ( 2010:194 ) kedisplinan adalah kesadaran seseorang menaati semua peraturan perusahaan dan norma sosial yang berlaku. Kesadaran adalah sikap seseorang yang secara sukarela mentaati semua peraturan dan sadar akan tugas dan tanggung jawabnya. Kesediaan adalah sikap, tingkah laku dan perbuatan seseorang yang sesuai dengan peraturan perusahaan baik yang tertulis maupun yang tidak tertulis.

Menurut Sedarmayanti ( 2010:10 ) kedisplinan merupakan salah satu fungsi manajemen sumber daya manusia dan kunci terwujudnya tugas, tanpa kedisiplinan akan sulit mewujudkan tujuan yang maksimal.

Menurut Muchadarsyah Sinungan ( 2005:142 ) disiplin kerja adalah sikap mental yang tercermin dalam perbuatan atau tingkah laku individu, kelompok, atau masyarakat berupa ketaatan terhadap peraturan-peraturan atau ketentuan yang ditetapkan untuk tujuan tertentu.

Berdasarkan pendapat-pendapat di atas dapat disimpulkan bahwa disiplin kerja adalah sikap dan perilaku karyawan/pegawai agar mampu untuk taat dan patuh terhadap peraturanperaturan yang berlaku baik tertulis maupun tidak tertulis dan sanggup menjalankannya.

\section{Jenis- Jenis Disiplin Kerja}

Menurut T. Hani Handoko ( 2007:208 ) disiplin kerja dibagi tiga, yaitu: a) Disiplin Preventif yaitu : kegiatan yang dilaksanakan untuk mendorong para karyawan agar mengikuti berbagai standar dan aturan, sehingga penyelewengan dapat dicegah; b) Disiplin Korektif yaitu : kegiatan yang diambil untuk menangani pelanggaran terhadap aturan-aturan yang mencoba unutk menghindari pelanggaranpelanggaran lebih lanjut. Kegiatan korektif sering berupa suatu bentuk hukuman dan disebut tindakan pendisiplinan; dan c) Disiplin Progresif yaitu : kegiatan memberikan hukuman-hukuman yang lebih berat terhadap pelanggaran-pelanggaran yang berulang. Tujuan dari disiplin progresif ini agar karyawan untuk mengambil tindakan-tindakan korektif sebelum mendapat hukuman yang lebih serius.

Dari pendapat di atas dapat diambil kesimpulan bahwa tujuan pembinaan disiplin kerja bertujuan agar dalam diri para karyawan mempunyai rasa disiplin sehingga diharapkan akan mendukung dalam pencapaian tujuan perusahaan/organisasi.

\section{Indikator-Indikator Disiplin Kerja}

Menurut Muchadarsyah Sinungan ( 2005:145 ) indikator-indikator dari disiplin kerja adalah sebagai berikut: a) Absensi, Adalah pendataan kehadiran karyawan yang sekaligus merupakan alat untuk melihat sejauh mana karyawan itu mematuhi peraturan yang berlaku dalam perusahaan; b) Sikap dan Perilaku, Adalah tingkat penyesuain diri seseorang dalam melaksanakan semua tugas-tugas dari atasannya 
termasuk melaksanakan peraturan perusahaan baik yang tertulis maupun tidak tertulis; dan c) Tanggung Jawab, Adalah hasil atau konsekuensi seorang karyawan atas tugas-tugas yang diserahkan kepadanya.

Sedangkan menurut T. Hani Handoko ( 2007:208 ) indikator-indikator dari disiplin kerja adalah: a) Kehadiran; b) Ketaatan; c) Ketepatan waktu dan d) Perilaku.

\section{Hubungan Disiplin Kerja Terhadap Produktivitas Kerja Karyawan}

Salah satu faktor untuk mencapai tujuan perusahaan diantaranya adalah peran sumber daya manusia atau karyawan. Sumber daya manusia dalam hal ini adalah tenaga kerja yang merupakan kekuatan pokok yang mampu menggerakan kegiatan perusahaan, dimana masing-masing individu memiliki latar belakang, tingkat ekonomi, sosial budaya yang berbeda-beda.

Tujuan dari suatu perusahaan adalah memperoleh keuntungan, tujuan tersebut akan diperoleh apabila produktivitas meningkat, untuk meningkatkan produktivitas kerja perlu adanya tenaga kerja yang memiliki keahlian dan ketrampilan kerja, karena apabila tenaga kerja tidak memiliki keahlian dan ketrampilan akan berakibat menurunkannya produktivitas dan merugikan perusahaan. Menurut Sumarsono (2010:63-64 ) produktivitas dipengaruhi oleh berbagai faktor baik yang berhubungan dengan tenaga kerja itu sendiri maupun faktor-faktor lainnya, seperti latar belakang pendidikan, ketrampilan, disiplin, motivasi, sikap dan etika kerja, gizi dan kesehatan, tingkat penghasilan, jaminan lingkungan dan iklim kerja, hubungan industrial,teknologi, sarana produksi, manajemen dan kesempatan berprestasi.

Produktivitas dipengaruhi oleh berbagai faktor baik yang berhubungan dengan tenaga kerja itu sendiri maupun faktor-faktor lain. Salah satu faktor-faktor tersebut adalah disiplin kerja. Produktivitas yang tinggi dapat dicapai jika didukung oleh para karyawan yang mempunyai disiplin kerja yang tinggi dalam melaksanakan tugas dan kewajibannya.

Mengacu pada pendapat Henry Simamora ( 2004:164 ) faktor-faktor yang digunakan dalam pengukuran produktivitas kerja meliputi kuantitas kerja; kualitas kerja; dan ketepatan waktu. Sedangkan faktor-faktor yang digunakan dalam pengukuran disiplin kerja meliputi ketepatan waktu; mampu memanfatkan dan menggunakan perlengkapan dengan baik; menghasilkan pekerjaan yang memuaskan; mengikuti cara kerja yang ditentukan oleh perusahaan; memiliki tanggung jawab yang tinggi.Berdasarkan teori-teori diatas dapat dikemukakan bahwa terdapat pengaruh antara disiplin kerja terhadap produktivitas kerja karyawan.

\section{Pengertian Produktivitas Kerja}

Ada beberapa pendapat mengenai definisi produktivitas. Menurut Hadari Nawawi dan H.M Martini Hadari ( 2006:100 ) produktivitas kerja karyawan adalah kemampuan personel atau karyawan untuk menghasilkan sesuatu dalam bekerja, yang dapat diketahui dari perbandingan antara hasil kerja individu dalam bentuk uang dengan biaya yang dikeluarkan untuk individu tersebut agar dapat menghasilkan sesuatu.

Menurut Sedarmayanti ( 2010 :57 ) produktivitas kerja adalah bagaimana menghasilkan atau meningkatkan hasil barang dan jasa setinggi mungkin dengan memanfaatkan sumber daya secara efisien. Oleh karena itu produktivitas sering diartikan sebagai rasio antara keluaran dan masukan antara satuan waktu tertentu.

\section{Menurut Malayu S.P Hasibuan (} 2010:105 ) produktivitas adalah sebagai perbandingan antara keluaran (output) dengan masukan (input). Produktivitas naik hanya dimungkinkan oleh adanya peningkatan efisiensi (waktu, bahan, tenaga) dan sistem kerja, teknik produksi, dan adanya peningktan keterampilan tenaga kerja.

Berdasarkan pendapat-pendapat di atas dapat disimpulkan bahwa produktivitas kerja adalah kemampuan personel atau karyawan untuk menghasilkan sesuatu dalam bekerja, yang dapat diketahui dari perbandingan (ratio) antara hasil kerja/keluaran (output) dengan masukan (input).

\section{Faktor-Faktor Yang Mempengaruhi Produktivitas Kerja \\ Tinggi rendahnya produktivitas sangat dipengaruhi oleh berbagai faktor penting.}


Nidaul Izzah dan Ida Ardiani, Pengaruh Kompensasi dan Disiplin Kerja ...

Dalam kaitannya dengan upaya meningkatkan produktivitas kerja karyawan, perusahaan harus memperhatikan faktor-faktor yang memiliki potensi untuk meningkatkan produktivitas kerja. Menurut Sedarmayanti ( 2010: 83 ) faktorfaktor yang mempengaruhi produktivitas kerja adalah sebagai berikut :

Sikap mental meliputi : 1 . Motivasi kerja, Pada umumnya yang mempunyai motivasi kerja yang tinggi akan bekerja dengan rajin, giat sehingga dengan begitu akan dapat mencapai produktivitas kerja yang tinggi; 2. Disiplin kerja, Orang yang mempunyai disiplin kerja yang tinggi, akan bertanggung jawab terhadap tugas-tugas yang diberikan kepadanya. Hal ini akan mendorong terwujudnya tujuan perusahaan. Sebab kedisiplinan adalah kunci keberhasilan suatu perusahaan dalam mencapai tujuannya dan produktivitas kerjapun akan meningkat; dan 3. Etika kerja, Pada umumnya orang yang mempunyai etika yang baik akan nampak dalam penampilan kerja sehari-hari, berupa kerja sama, kehadiran, antusias, inisiatif, tanggung jawab terhadap pekerjaan, dan kreativitas. Wujud tersebut akan memberikan pengaruh besar terhadap pencapaian produktivitas kerja karyawan yang optimal.

Pendidikan, Pada umumnya orang yang mempunyai pendidikan yang lebih tinggi akan memiliki wawasan yang lebih luas terutama penghayatan akan pentingnya produktivitas.

Lingkungan perusahaan, Lingkungan perusahaan merupakan tempat dimana keberadaan dari perusahaan tersebut, dimana letaknya dapat dengan mudah dijangkau oleh para pekerja atau letaknya tidak jauh dari tempat para pekerja tinggal sehingga akan memperlancar dan para pekerja datang tepat waktu.

Jaminan sosial tenaga kerja (Jamsostek), Jaminan sosial yang diberikan oleh suatu perusahaan kepada karyawannya dimaksudkan untuk meningkatkan pengabdian dan semangat kerja. Apabila jaminan sosial karyawan mencukupi, maka akan mneimbulkan produktivitas kerja yang meningkat.
Insentif, Insentif adalah salah satu program perusahaan untuk memberikan motivasi kepada para pekerja agar mereka bekerja lebih keras lagi sehingga produktivitas kerja mereka meningkat. Insentif merupakan salah satu bentuk penghargaan dari perusahaan kepada karyawan yang berprestasi dan diberikan diluar upah haruan, upah lembur yang diterima karyawan.

Sarana Produksi, Mutu sarana produksi berpengaruh terhadap peningkatan produktivitas kerja. Karena dengan mutu sarana produksi yang baik, seorang dapat bekerja dengan baik pula dan akan meningkatkan produktivitas kerja karyawan.

\section{Indikator-Indikator Produktivitas Kerja,} Menurut Sedarmayanti ( 2010:57 ) indikatorindikator dari produktivitas kerja adalah sebagai berikut: a) Bertugas atau bekerja tidak sekedar memenuhi kualifikasi pekerjaan; b) Memiliki motivasi yang tinggi; c) Memiliki orientasi kerja yang positif; d) Bertanggung jawab; e) Dapat bergaul dengan efektif.

Sedangkan menurut Gerry Dessler ( 2007:188 ) indikator-indikator produktivitas kerja adalah sebagai berikut : a) Kualitas hasil kerja, yaitu mutu hasil kerja yang didasarkan pada standar yang ditetapkan. Biasanya diukur melalui ketetapan, ketelitian, keterampilan dan keberhasilan hasil kerja, b) Kuantitas hasil kerja, yaitu banyaknya hasil kerja sesuai dengan waktu kerja yang ada, yang perlu diperhatikan bukan hasil rutin tetapi seberapa cepat pekerjaan dapat terselesaikan, c) Disiplin kerja, yaitu bentuk ketaatan dari perilaku seseorang dalam mematuhi ketentuan-ketentuan ataupun peraturan-peraturan tertentu yang berkaitan dengan pekerjaan, dan diberlakukan dalam suatu organisasi atau perusahaan, d) Kerja lembur, yaitu segala pekerjaan yang harus dilakukan seorang karyawan pada waktu-waktu tertentu di luar waktu kerja sebagaimana telah ditetapkan bagi oleh perusahaan.

Menurut Sedarmayanti ( 2010 :83 ) faktor-faktor yang mempengaruhi tinggi rendahnya produktivitas kerja karyawan adalah disiplin kerja, pendidikan, lingkungan perusahaan, kompensasi, dan sarana produksi. Peningkatan daya saing perusahaan dapat 
dicapai, salah satunya dengan cara memenuhi pesanan pelanggan tepat pada waktunya. PT Mulia Makmur Elektrikatama merupakan perusahaan yang bersifat make-to-order, pemenuhan order dengan harga yang kompetitif dan tepat waktu merupakan poin penting untuk mendapatkan kredibilitas yang baik oleh para pelanggan perusahaan. Kredibilitas yang baik dapat meningkatkan posisi perusahaan dalam pasar dan dapat meningkatkan kemungkinan penerimaan pesanan (order) yang lebih banyak sehingga profit perusahaan dapat meningkat pula.

Dari data Monitoring Productivity tahun 2010 sampai 2011 menunjukkan bahwa produktivitas yang ditargetkan perusahaan sebanyak 30 panel box per bulan belum pernah tercapai. Hasil perhitungan rata-rata (average) produktivitas kerja karyawan pada tahun 2010 shift I sebesar 88\%, tahun 2011 shift I sebesar $82 \%$. Sedangkan pada tahun 2010 shift II ratarata produktivitas sebesar $82 \%$, tahun 2011 shift II sebesar $81 \%$. Hal ini menunjukkan bahwa produktivitas kerja karyawan pada tahun 2011 mengalami penurunan dibandingkan dengan tahun 2010.

Banyak ketidakpuasan karyawan di suatu perusahaan berasal dari pemberian kompensasi yang dianggap belum memadai, tidak adil dan tidak ada kejelasan dalam kebijakannya. Sesuai dengan peraturan perusahaan PT Mulia Makmur Elektrikatama: 1. Pasal 19 Bab V Mengenai Kompensasi Upah: 1.a) Upah diberikan pada karyawan pada akhir bulan berjalan dalam tahun takwim, Berdasarkan hasil wawancara ditemukan fakta bahwa upah yang diberikan perusahaan ada kalanya diterima melewati tanggal yang seharusnya (sumber wawancara); dan 1.b) Upah untuk karyawan yang masa kerjanya minimal 5 (lima) tahun, perusahaan akan mengkhususkan nilai kenaikkan upah tersebut, Berdasarkan hasil wawancara ditemukan fakta bahwa masih ada karyawan yang belum mendapatkan kenaikkan upah padahal masa kerja sudah lebih dari 5 (lima) tahun ( sumber wawancara ); 2. Pasal 29 Bab VIII Mengenai Jaminan Sosial dan Kesejahteraan Karyawan: 2.a) Jaminan sosial dan kesejahteraan karyawan adalah bantuan yang diberikan perusahaan kepada karyawan dalam rangka perlindungan, perawatan, dan kesejateraan karyawan. Berdasarkan hasil wawancara ditemukan fakta bahwa pelaksanaannya untuk jaminan sosial dan kesejahteraan karyawan termasuk pemeliharaan kesehatan karyawan diserahkan sepenuhnya kepada PT JAMSOSTEK (perusahaan tidak memberi kompensasi atau pembayaran langsung terhadap pemeliharaan kesehatan kepada para karyawan) ( sumber wawancara ).

Disiplin kerja merupakan salah satu faktor yang terpenting dalam meningkatkan produktivitas kerja karyawan, karena dengan adanya disiplin kerja karyawan akan mampu mencapai produktivitas kerja yang maksimal. Tingkat disiplin dapat diukur melalui ketaatan pada peraturan yang telah ditentukan oleh perusahaan dan dari kesadaran pribadi. apabila disiplin kerja tidak dilakukan, maka akan menghambat target perusahaan sesuai apa yang ditetapkan sebelumnya oleh perusahaan. Sesuai dengan peraturan perusahaan PT Mulia Makmur Elektrikatama: 1. Pasal 30 Mengenai Seragam dan Kelengkapan Kerja : 1.a) Pada waktu bekerja karyawan diwajibkan mengenakan pakaian kerja (seragam) yang sopan dan rapih sesuai dengan lingkungan kerja. Berdasarkan hasil pengamatan ditemukan fakta bahwa hampir 90\% karyawan menggunakan pakaian kerja (seragam) yang sopan dan rapih sesuai dengan lingkungan kerja ( sumber wawancara ); dan 1.b) Perusahaan menyediakan Alat pelindung Diri (APD) guna menjamin keselamatan dan kesehatan kerja karyawan.Berdasarkan hasil pengamatan ditemukan fakta bahwa hanya 30\% karyawan yang menggunakan Alat Pelindung Diri (APD) pada saat bekerja. Contoh : Karyawan yang bekerja di bagian welding (pengelasan) hanya $10 \%$ yang menggunakan Alat Pelindung Diri (APD) yang berupa topeng untuk menghindari karyawan dari percikan api; dan 2. Pasal 35 Mengenai Pedoman Tata Tertib dan Disiplin: 2.a) Salama berada di lingkungan perusahaan, karyawan wajib memakai kartu tanda pengenal karyawan (Id Card).Berdasarkan hasil pengamatan ditemukan fakta bahwa hampir $60 \%$ karyawan tidak menggunakan kartu tanda pengenal karyawan (Id Card); dan 2.b) Setiap karyawan wajib hadir (mulai bekerja dan meninggalkan pekerjaan) pada waktu yang telah 
Nidaul Izzah dan Ida Ardiani, Pengaruh Kompensasi dan Disiplin Kerja ...

ditetapkan oleh perusahaan dan mencatat kehadirannya saat masuk dan pulang.

Dari data dari perusahaan menunjukkan fakta bahwa hampir $40 \%$ karyawan masuk dan pulang tidak tepat waktu yang sesuai ditetapkan oleh perusahaan. Gejala-gejala kerja yang kurang baik seperti di atas dapat mempengaruhi pencapaian target perusahaan. Berbagai upaya untuk meningkatkan produktivitas kerja karyawan dilakukan oleh perusahaan. Salah satu cara umum adalah melalui kebijakan kompensasi. Pemberian kompensasi sebenarnya merupakan salah satu faktor pendorong kerja. Kompensasi merupakan daya tarik dengan tujuan untuk membangun, memelihara dan memperkuat harapan-harapan karyawan bahwa dalam melakukan sesuatu mereka akan mendapatkan imbalan yang dapat memenuhi kebutuhannya.

\section{Kerangka Pemikiran}

Kepuasan kerja karyawan merupakan salah satu program pemeliharaan karyawan yang bertujuan untuk menciptakan kondisi dan lingkungan kerja yang menyenangkan yang secara tidak langsung berkaitan erat dengan produktivitas kerja karyawan. PT. Mulia Makmur Elektrikatama merupakan perusahaan yang bergerak di bidang elektronika (pembuatan, perakitan, berbagai peralatan dan panel listrik) yang dalam kegiatannya menggunakan faktor-faktor produksi, seperti modal, material, mesin dan tenaga kerja (sumber daya manusia). Salah satu upaya dalam pemeliharaan karyawan yang dilakukan oleh PT. Mulia Makmur Elektrikatama salah satunya adalah dengan pemberian kompensasi.

Dalam lingkungan PT. Mulia Makmur Elektrikatama kedisiplinan dinyatakan melalui nilai-nilai seperti kehadiran, ketaatan terhadap prosedur kerja dan ketertiban. Hal tersebut merupakan beberapa acuan disiplin kerja yang menjadi tolak ukur tingkat kedisiplinan pada PT. Mulia Makmur Elektrikatama. Ketaatan terhadap prosedur kerja merupakan bagian dari sebuah kedisiplinan yang ditunjukkan dengan pemahaman atas suatu bidang pekerjaannya dan menjalankannya sesuai dengan mekanisme kerja yang telah ditetapkan oleh perusahaan. Ketertiban ditunjukkan dengan adanya sikap sense of belonging atau rasa kepemilikan untuk menjaga lingkungan kerja beserta fasilitas- falitas pendukung pekerjaan yang digunakan dalam aktivitas kerja.

\section{Hipotesis}

Berdasarkan latar belakang dan kerangka pemikiran yang sudah diuraikan di atas, maka dapatlah dibuatkan rancangan hipotesis sebagai berikut: 1. 1. Diduga ada pengaruh kompensasi terhadap produktivitas kerja karyawan pada PT. Mulia Makmur Elektrikatama; 2. Diduga ada pengaruh disiplin kerja terhadap produktivitas kerja karyawan pada PT. Mulia Makmur Elektrikatama; dan 3. 3. Diduga ada pengaruh kompensasi dan disiplin kerja terhadap produktivitas kerja karyawan pada PT. Mulia Makmur Elektrikatama.

\section{Metode Pengumpulan Data}

Dalam penelitian ini diperlukan data kualitatif dan data kuantitatif oleh karena itu penulis menggunakan beberapa metode pengumpulan data, yaitu sebagai berikut : a) Metode Penelitian Lapangan (Field Research Method), b) Metode Penelitian Kepustakaan (Library Research Method)

\section{Populasi dan Metode Pengambilan Sampel}

Populasi dalam penelitian ini adalah karyawan divisi mechanical PT. Mulia Makmur Elektikatama yang berjumlah 41 orang (tidak melihat strata dalam divisi mechanical).

Dalam mendapat kemungkinan benar jawaban responden untuk dapat dipertanggung jawabkan secara ilmiah, maka dalam penelitian ini dilakukan penarikan sampel dengan teknik "random sampling" atau "sampel acak" yaitu teknik penetuan sempel berdasarkan acak. Sampel yang digunakan sebagai responden dalam penelitian ini sebanyak 30 orang karyawan, karena jumlah tersebut sudah dianggap mewakili dari populasi yang ada di Divisi Mechanical pada PT. Mulia Makmur Elektirkatama.

\section{Metode Analisis Data}

Metode analisis yang digunakan dalam peneltian ini adalah analisis kualitatif dan kuantitatif. Analisis kualitatif adalah analisis yang digunakan untuk menggambarkan variabel-variabel penelitian yaitu variabel kompensasi, disiplin kerja dan produktivitas 
kerja, sedangkan analisis kuantitatif digunakan untuk menguji variabel-variabel penelitian, dengan menggunakan statistik. Alat statistik yang digunakan adalah regresi korelasi sederhana maupun berganda.

\section{Definisi dan Pengukuran Variabel}

Dalam pokok bahasan ini terdiri dari tiga variabel yaitu kompensasi $\left(\mathrm{X}_{1}\right)$, disiplin kerja $\left(\mathrm{X}_{2}\right)$ dan produktivitas kerja $(\mathrm{Y})$ masing-masing variabel mempunyai definisi sebagai berikut: a). Kompensasi ( $\mathrm{X}_{1}$ ), Kompensasi adalah semua bentuk pembayaran yang diberikan oleh perusahaan kepada karyawan sebagai balas jasa atas pelaksanaan tugas atau kontribusi karyawan kepada perusahaan. Dijabarkan dengan indikator kompensasi berikut ini : jaminan asuransi, pengembangan karir, kenaikan penghasilan, tunjangan jabatan, kenyamanan tugas, persahabatan, insentif, dan pembayaran tidak masuk kantor; b). Disiplin Kerja (X2), Disiplin kerja adalah sikap dan perilaku karyawan/pegawai agar mampu untuk taat dan patuh terhadap peraturan-peraturan yang berlaku baik tertulis maupun tidak tertulis dan sanggup menjalankannya. Dijabarkan dengan indikator disiplin kerja sebagai berikut ini : kehadiran, ketaatan, sikap dan perilaku, dan tanggung jawab; dan c) Produktivitas Kerja (Y), Produktivitas kerja adalah kemampuan personel atau karyawan untuk menghasilkan sesuatu dalam bekerja, yang dapat diketahui dari perbandingan (ratio) antara hasil kerja/keluaran (output) dengan masukan (input). Dijabarkan dengan indikator produktivitas kerja sebagai berikut : bertugas atau bekerja tidak sekedar memenuhi kualifikasi pekerjaan, memiliki motivasi yang tinggi, memiliki orientasi kerja yang positif, bertanggung jawab dan dapat bergaul dengan efektif.

\section{Analisis Deskriptif Responden}

Deskriptif responden merupakan gambaran umum dari para responden. Berdasarkan hasil pengolahan data (tabulasi) terhadap angket (daftar pertanyaan terstruktur yang disebarkan kepada 30 (tiga puluh) responden dari populasi 41 (empat puluh satu) orang diperoleh karakteristik responden sebagai berikut :

\section{Karakteristik Responden Berdasarkan Jenis Kelamin}

Pengelompokan responden berdasarkan jenis kelamin dibagi menjadi 2 (dua) kelompok, yaitu kelompok pria dan kelompok wanita. Dari hasil penelitian terhadap 30 responden, diketahui bahwa 27 orang atau $90 \%$ berjenis kelamin pria sedangkan sisanya sebanyak 3 orang atau $10 \%$ berjenis kelamin wanita. Adapun persentase responden berdasarkan jenis kelamin secara rinci dapat dilihat pada tabel di bawah ini:

\section{Karakteristik Responden Berdasarkan Kelompok Usia}

Pengelompokan responden berdasarkan kelompok usia dibagi menjadi 4 (empat) kelompok, yaitu : antara 21 sampai dengan 26 tahun, antara 27 sampai dengan 33 tahun, antara 34 sampai dengan 40 tahun, dan lebih dari 41 tahun ke atas. Dari hasil penelitian terhadap 30 responden yang ada, ditemukan bahwa responden paling banyak yang berusia antara 21 sampai dengan usia 26 tahun, yaitu sebanyak 11 orang atau $40.98 \%$, dan terendah sebanyak 1 orang responden atau $6.56 \%$ berusia 41 tahun ke atas.

\section{Karakteristik Responden Berdasarkan Tingkat Pendidikan}

Pengelompokan responden berdasarkan tingkat pendidikan dibagi menjadi 3 (tiga), yaitu : SLTA, Diploma III, dan Sarjana. Dari hasil penelitian diperoleh data bahwa, mayoritas responden yaitu 21 orang responden $(70.00 \%)$ adalah berpendidikan SLTA dan terendah 2 orang responden $(6.67 \%)$ adalah berpendidikan Diploma III.

\section{Analisis Data Kuantitatif}

Analisis kuantitatif adalah analisis yang digunakan untuk menguji variabel - variabel antara Kompensasi $\left(\mathrm{X}_{1}\right)$, Disiplin Kerja $\left(\mathrm{X}_{2}\right)$ dan Produktivitas Kerja (Y). Untuk menguji variabel penelitian tersebut menggunakan perhitungan statistik yaitu analisis regresi, korelasi sederhana dan berganda.

\section{Analisis Regresi Sederhana Antara Kompensasi $\left(\mathrm{X}_{1}\right)$ Dengan Produktivitas Kerja Karyawan (Y)}


Nidaul Izzah dan Ida Ardiani, Pengaruh Kompensasi dan Disiplin Kerja ...

Berdasarkan data yang ada maka untuk memperoleh garis linier yang ditetapkan melalui titik koordinat atau titik taksir (estimating line) maka garis regresi memiliki persamaan sebagai berikut:

$\mathrm{Y}=\mathrm{a}+\mathrm{bX} 1$

$Y=13,179+0,657 X_{1}$

$\mathrm{a}=13,179$ artinya apabila variabel $\mathrm{X}_{1}$ (kompensasi) mempunyai nilai sebesar 0 (tidak ada) maka variabel Y (produktivitas kerja) mempunyai nilai sebesar 13,179.

$\mathrm{b}=0,657$ artinya apabila setiap kenaikan variabel $\mathrm{X}_{1}$ (kompensasi) sebesar 1 unit, maka akan menaikan variabel $Y$ (produktivitas kerja) sebesar 0,657 unit dengan konstanta 13,179 dan sebaliknya.

\section{Analisis Korelasi Sederhana Antara Kompensasi ( $\left.\mathrm{X}_{1}\right)$ Dengan Produktivitas Kerja Karyawan (Y)}

Dari hasil perhitungan diketahui bahwa nilai koefisien korelasi (r) adalah 0,622. Hal ini menunjukkan bahwa derajat hubungan antara variabel kompensasi (X1) terhadap variabel produktivitas (Y) kerja adalah kuat.

\section{Koefisien Penentu}

Untuk menganalisis besarnya kontribusi (pengaruh) variabel kompensasi $\left(\mathrm{X}_{1}\right)$ terhadap variabel produktivitas (Y) digunakan rumus koefisien penentu (KP) yaitu : $\mathrm{KP}=(\mathrm{r})^{2} \mathrm{x}$ $100 \%$ Dari hasil perhitungan diperoleh nilai koefisien penentu adalah $38,69 \%$. Hal ini berarti kontirbusi (pengaruh) variabel kompensasi ( $\left.\mathrm{X}_{1}\right)$ terhadap prodktivitas kerja karyawan (Y) sebesar $38,69 \%$ sedangkan sisanya $61,31 \%$ dipengaruhi oleh faktor-faktor lain yang tidak diteliti dalam penelitian ini.

\section{Uji Hipotesis t (h)}

Untuk menguji tingkat signifikan variabel kompensasi $\left(\mathrm{X}_{1}\right)$ terhadap produktivitas kerja (Y) maka digunakan rumus uji $\mathrm{t}$ atau $\mathrm{t}$ hitung, yaitu : $\mathbf{t}(\mathbf{h})=\mathbf{4 , 2 0 4}$ Dalam uji hipotesis ini derajat kepercayaan (degree of freedom) atau DF $\infty$ yang digunakan adalah 5\% sehingga tabel atau too/2 ( $\mathbf{n}-\mathbf{2})$ atau t0,25 (30-2) atau t0,25 (28) adalah sebesar 2,048. Jika dibandingkan antara nilai thitung dengan ttabel maka thitung > tabel atau 4,204 > 2,048 maka $\mathrm{H}_{\mathrm{o}}$ ditolak dan $\mathrm{H}_{\mathrm{a}}$ diterima. Dengan demikian ada hubungan kompensasi (X1) terhadap produktivitas kerja karyawan $(\mathrm{Y})$.

\section{Analisis Regresi Sederhana Antara Disiplin Kerja (X2) Dengan Produktivitas Kerja Karyawan (Y)}

Analisis regresi terhadap data yang ada, diperoleh persamaan regresi linier sederhana: $\mathrm{Y}=\mathbf{7 , 2 0 6}+\mathbf{0 , 8 3 2 \mathrm { X } _ { 2 }}$

$a=7,206$ artinya apabila variabel disiplin kerja (X2) mempunyai nilai sebesar 0 (tidak ada) maka variabel produktivitas kerja (Y) mempunyai nilai sebesar 7,206.

$\mathrm{b}=0,832$ artinya apabila setiap kenaikan variabel disiplin kerja $\left(\mathrm{X}_{2}\right)$ sebesar 1 unit maka akan menaikkan variabel produktivitas kera (Y) sebesar 0,832 unit dengan nilai konstanta 7,206 dan sebaliknya.

\section{Analisis Korelasi Sederhana Antara Disiplin Kerja (X2)Dengan Produktivitas Kerja Karyawan (Y)}

Dari hasil perhitungan diketahui bahwa nilai koefisien korelasi (r) adalah 0,856. Hal ini menunjukkan bahwa derajat hubungan antara variabel disiplin kerja $\left(\mathrm{X}_{2}\right)$ terhadap produktivitas kerja (Y) adalah sangat kuat.

\section{Koefisien Penentu}

Untuk menganalisis besanya kontribusi (pengaruh) variabel disiplin kerja $\left(\mathrm{X}_{2}\right)$ terhadap produktivitas kerja (Y) digunakan rumus koefisien penentu $(\mathrm{KP})$ yaitu: $\mathrm{KP}=(\mathrm{r}) 2 \times 100 \%$ $=(0,856) 2 \times 100 \%=0,7327 \times 100 \%=\mathbf{7 3}, \mathbf{2 7} \%$ Dari hasil perhitungan di atas, maka nilai koefisien penentu adalah $73,27 \%$. Hal ini berarti kontribusi (pengaruh) variabel disiplin kerja $\left(\mathrm{X}_{2}\right)$ terhadap produktivitas kerja $(\mathrm{Y})$ sebesar $73,27 \%$ sedangkan sisanya $26,73 \%$ dipengaruhi oleh faktor-faktor yang tidak diteliti dalam penelitian ini.

\section{Uji Hipotesis t (h)}

Untuk menguji tingkat signifikan variabel disiplin kerja $\left(\mathrm{X}_{2}\right)$ terhadap produktivitas kerja (Y) maka digunakan rumus uji $\mathrm{t}$ atau $\mathrm{t}$ hitung, dan diperoleh $\mathbf{t}(\mathbf{h})=\mathbf{8 , 7 6 2}$. Dalam uji hipotesis ini derajat kepercayaan (degree of freedom) atau DF $\infty$ yang digunakan adalah 5\%, sehingga tabel atau to/2 (n2) atau t0,25 (30-2) atau t0,25 (28) adalah sebesar 2,048. Jika dibandingkan antara nilai thitung 
dengan tabel maka thitung > tabel atau 8,762 > 2,048 maka $\mathrm{H}_{\mathrm{o}}$ ditolak dan $\mathrm{H}_{\mathrm{a}}$ diterima. Dengan demikian ada hubungan disiplin kerja $\left(\mathrm{X}_{2}\right)$ dengan produktivitas kerja (Y).

\section{Analisis Regresi Berganda Antara Kompensasi $\left(\mathrm{X}_{1}\right)$ dan Disiplin Kerja $\left(\mathrm{X}_{2}\right)$ dengan Produktivitas Kerja (Y)}

Berdasarkan perhitungan regresi

berganda dengan menggunakan data yang ada maka untuk memperoleh garis linear yang ditetapkan melalui titik koordinat atau garis taksir (estimating line) maka garis regresi berganda memiliki persamaan sebagai berikut : $\mathrm{Y}=\mathrm{a}+\mathrm{b}_{1} \mathrm{X}_{1}+\mathrm{b}_{2} \mathrm{X}_{2}$ dan diperoleh hasil $\mathrm{Y}=$ $\mathbf{0 , 0 1 0 2}+\mathbf{0 , 2 1 4 9 X} \mathrm{X}_{1}+\mathbf{0 , 7 9 9 8 X _ { 2 }}$. Konstanta atau $\mathrm{a}=0,0102$ artinya apabila variabel kompensasi $\left(\mathrm{X}_{1}\right)$ dan variabel disiplin kerja $\left(\mathrm{X}_{2}\right)$ mempunyai nilai sebesar 0 (tidak ada) maka variabel produktivitas kerja (Y) mempunyai nilai sebesar $0,0102, \mathrm{~b}_{1}=0,2149$ artinya apabila setiap kenaikan variabel kompensasi $\left(\mathrm{X}_{1}\right)$ sebesar 1 unit, maka akan menaikkan variabel produktivitas (Y) sebesar 0,2149 unit dimana disiplin kerja ( $\left.\mathrm{X}_{2}\right)$ dianggap tetap (konstan), $\mathrm{b}_{2}=$ 0,7998 artinya apabila setiap kenaikan variabel disiplin kerja $\left(\mathrm{X}_{2}\right) 1$ unit, maka akan menaikkan variabel produktivitas kerja (Y) sebesar 0,7998 unit dimana kompensasi ( $\left.\mathrm{X}_{1}\right)$ dianggap tetap (konstan).

Analisis Korelasi Berganda antara Kompensasi (X1) dan Disiplin Kerja (X2) dengan Produktivitas Kerja (Y)

Korelasi berganda digunakan untuk mengetahui keeratan hubungan antara variabel kompensasi (X1) dan disiplin kerja (X2) dengan produktivitas kerja (Y). Perhitungan korelasi berganda menggunakan pendekatan Anova (Analysis of Varians) yaitu dengan rumus korelasi berganda adalah sebagai berikut $: R=V$ SSR / SST

Keterangan :

$\mathrm{R} \quad=$ koefisien korelasi berganda

SSR $=$ Sum Square Regresi

$2 / \mathrm{n}$

$$
=a \Sigma Y+b_{1} \Sigma X_{1} Y+b_{2} \Sigma X_{2} Y-(\Sigma Y)
$$

$=0,0102(1168)+0,2149(45882)+$

$0,7998(44684)-(1168)^{2} / 30$

$=11,914+9860,042+35738,263-$

$(1364224 / 30)$

$$
\begin{aligned}
& =45610,219-45474,133 \\
& =\mathbf{1 3 6 , 0 8 6} \\
\text { SST } & =\text { Sum Square Total } \\
& =\sum Y 2-\left(\sum Y\right)_{2}^{2} / \mathrm{n}=45638-(1168) \\
2 / 30= & 45638-45474,133=\mathbf{1 6 3 , 8 6 7}
\end{aligned}
$$

$\mathrm{SSE}=\mathrm{SST}-\mathrm{SSR}=163,867-136,086=$ 27,781

$\mathrm{R}=\sqrt{\mathrm{SSR}} / \mathrm{SST}=\sqrt{136,086} /$

$163,867=\sqrt{ } 0,8305=\mathbf{0 , 9 1 1 3}$

Dari hasil perhitungan diketahui bahwa nilai koefisien korelasi berganda (R) adalah 0,9113. Hal ini menunjukkan bahwa derajat hubungan antara variabel kompensasi $\left(\mathrm{X}_{1}\right)$ dan disiplin kerja $\left(\mathrm{X}_{2}\right)$ dengan variabel prduktivitas kerja (Y) adalah sangat tinggi.

\section{Koefisien Penentu Berganda}

Untuk menganalisis besarnya kontribusi (pengaruh) variabel kopensasi $\left(\mathrm{X}_{1}\right)$ dan disiplin $\operatorname{kerjaK}\left(\mathrm{X}_{2}\right)$ dengan produktivitas kerja (Y) digunakan rumus koefisien penentu $(\mathrm{KP})=\mathrm{R} 2 \mathrm{X}$ $100 \%$

$=(0,9113) 2 \times 100 \%=0,8305 \times 100 \%=$ $83,05 \%$

Dari hasil di atas maka nilai koefisien penentu adalah $=83,05 \%$. Hal ini berarti kontribusi (pengaruh) variabel kompensasi $\left(\mathrm{X}_{1}\right)$ dan disiplin kerja $\left(\mathrm{X}_{2}\right)$ dengan produktivitas kerja (Y) sebesar $83,05 \%$ sedangkan sisanya $16,95 \%$ dipengaruhi oleh faktor-faktor lain yang tidak diteliti dalam penelitian ini.

\section{Pengujian Hipotesis Berganda}

Uji signifikan korelasi berganda antara kompensasi $\left(\mathrm{X}_{1}\right)$ dan disiplin kerja $\left(\mathrm{X}_{2}\right)$ dengan produktivitas kerja (Y) dengan tahapan-tahapan pengujian sebagai berikut :

\section{Menentukan hipotesis}

Ho : $r=0$, tidak terdapat hubungan antara kompensasi $\left(\mathrm{X}_{1}\right)$ dan disiplin kerja $\left(\mathrm{X}_{2}\right)$ dengan produktivitas kerja (Y) pada PT Mulia Makmur Elektrikatama.

Ha $: r \neq 0$, terdapat hubungan antara kompensas $\mathrm{i}\left(\mathrm{X}_{1}\right)$ dan disiplin kerja $\left(\mathrm{X}_{2}\right)$ dengan produktivitas kerja (Y) pada PT Mulia Makmur Elektrikatama.

\section{Menentukan F tabel}


Nidaul Izzah dan Ida Ardiani, Pengaruh Kompensasi dan Disiplin Kerja ...

$$
\begin{aligned}
& \mathrm{F} \text { tabel }=\mathrm{F} \mathrm{a} ;(\mathrm{k}, \mathrm{n}-\mathrm{k}-1)=\mathrm{F} 5 \% ;(2 ; 30-2- \\
& 1)=\mathrm{F} 5 \%(2 ; 27)=\mathbf{3 , 3 5}
\end{aligned}
$$

\section{Menentukan F hitung}

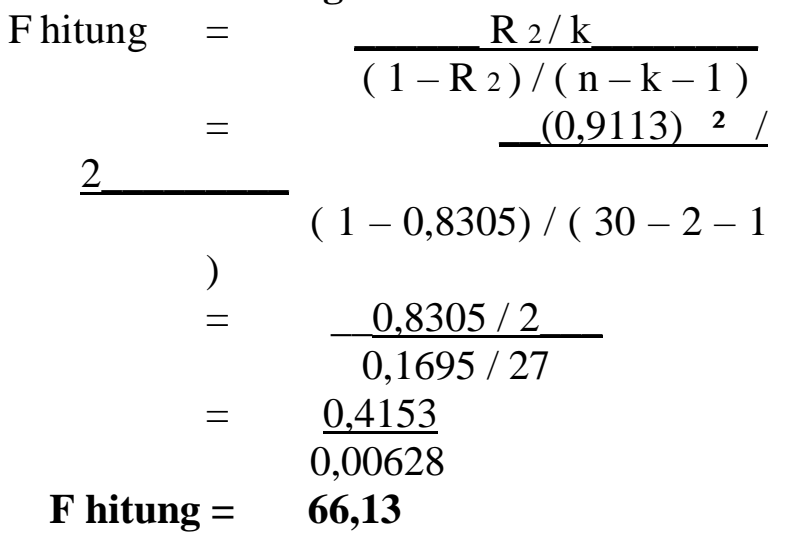

\section{Kesimpulan}

Hasil analisis dengan menggunakan perhitungan regresi sederhana diperoleh $\mathrm{Y}=$ $13,179+0,657 \mathrm{X}_{1}$. Hal ini menunjukkan bahwa kompensasi $\left(\mathrm{X}_{1}\right)$ berpengaruh positif terhadap produktivitas kerja (Y) dimana setiap kenaikan kompensasi sebesar 1 akan menaikan produktivitas sebesar 0,657. Sedangkan hasil analisis dengan menggunakan perhitungan korelasi sederhana diperoleh $\mathrm{r}=0,622$ dan $\mathrm{KP}$ sebesar 38,69\% yang berarti ada hubungan positif dan kuat antara kompensasi terhadap produktivitas kerja. Adapun hasil uji-t menunjukkan thitung $>$ tabel atau 4,204 > 2,048 yang berarti adanya hubungan yang signifikan antara kompensasi $\left(\mathrm{X}_{1}\right)$ terhadap produktivitas kerja (Y).

Hasil analisis dengan menggunakan perhitungan regresi sederhana diperoleh $\mathrm{Y}=$ $7,206+0,832 X_{2}$. Hal ini menunjukkan bahwa disiplin kerja $\left(\mathrm{X}_{2}\right)$ berpengaruh positif terhadap produktivitas kerja (Y) dimana setiap kenaikan disiplin kerja sebesar 1 akan menaikan produktivitas sebesar 0,832. Sedangkan hasil analisis dengan menggunakan perhitungan korelasi sederhana diperoleh $\mathrm{r}=0,856$ dan $\mathrm{KP}$ sebesar $73,27 \%$ yang berarti ada hubungan positif dan sangat kuat antara kompensasi terhadap produktivitas kerja. Adapun hasil uji-t menunjukkan thitung $>$ tabel atau 8,762 > 2,048 yang berarti adanya hubungan yang signifikan antara disiplin kerja $\left(\mathrm{X}_{2}\right)$ terhadap produktivitas kerja (Y).

Hasil analisis dengan menggunakan regresi berganda diperoleh $\mathrm{Y}=0,0102+0,2149 \mathrm{X} 1+$ $0,7998 X 2$ dengan $b_{1}=0,2149$ mempunyai arti hubungan kompensasi (X1) terhadap produktivitas kerja $(\mathrm{Y})$ positif dan $\mathrm{b}_{2}=0,7998$ mempunyai arti hubungan disiplin kerja $\left(\mathrm{X}_{2}\right)$ terhadap produktivitas kerja (Y) positif. Sedangkan dari hasil analisis dengan menggunakan korelasi berganda diperoleh $\mathrm{R}=$ 0,9113 dan $\mathrm{KPB}=83,05 \%$ yang berarti derajat hubungan antara kompensasi dan disiplin kerja terhadap produktivitas kerja sangat kuat. Adapun hasil uji-F menunjukkan Fhitung $>$ Ftabel atau 66,13> 3,35 yang berarti semua variabel bebas $\left(\right.$ kompensasi $=\mathrm{X}_{1}$ dan disiplin kerja $=\mathrm{X}_{2}$ ) secara bersama-sama terdapat pengaruh yang signifikan terhadap variabel produktivitas kerja (Y) pada karyawan PT Mulia Makmur Elektrikatama.

\section{Saran}

Karena hasil kuesioner tentang variabel kompensasi menunjukkan bahwa klaim asuransi pengobatan mempunyai skor paling rendah, maka sebaiknya perusahaan lebih memperhatikan klaim asuransi pengobatan agar produktivitas kerja karyawan dapat meningkat. Kedisiplinan karyawan perusahaan sudah bagus, akan tetapi harus lebih ditingkatkan terutama dalam hal penggunaan perlengkapan kantor.

\section{DAFTAR PUSTAKA}

A.A. Mangkunegara, 2007, Manajemen Sumber Daya Manusia, Bandung : Refika Editama

Bambang Kusriyanto, 2001, Meningkatkan Produktivitas Kerja Karyawan, Jakarta : Pustaka Binaman Pressindo

Dessler, Garry 2007, Manajemen Sumber Daya Manusia, Jakarta : Indeks

Edy Sutrisno, 2009, Manajemen Sumber Daya Manusia, Jakarta: Kencana Prenada Media Group

Hadari Nawawi dan Martini Hadari, 2006, Administrasi Personel Untuk Peningkatan Produktivitas Kerja, Jakarta : CV Masagung

Henry Simamora, 2004, Manajemen Sumber Daya Manusia, Jakarta : PT Bumi Aksara J. Supranto, 2008, Statistik, Jakarta : Erlangga

Malayu S.P. Hasibuan, 2010, Manajemen Sumber Daya Manusia, Jakarta : PT Bumi Aksara 
Majalah Ilmiah Ilmu Administrasi

ISSN 1411-0830

Sedarmayanti, 2010, Sumber Daya Manusia dan Produktivitas Kerja, Bandung : CV Mandar Maju

Sugiyono, 2000, Metode Untuk Penelitian, Bandung : CV Alfabeta
T. Hani Handoko, 2007, Manajemen Personalia dan Sumber Daya Manusia, Yoyyakarta: BPFE 